\title{
Oględziny i dokumentacja zdarzeń o charakterze upadku z wysokości w terenie eksponowanym i jaskiniach z udziałem ratowników Grupy Jurajskiej Górskiego Ochotniczego Pogotowia Ratunkowego
}

\author{
MAREK LISOWICZ \\ ORCID: 0000-0003-1453-5172 \\ Grupa Regionalna GOPR — Grupa Jurajska \\ TOMASZ MOTYL \\ ORCID: 0000-0001-6254-4642 \\ Grupa Regionalna GOPR — Grupa Jurajska
}

Przedstawiona poniżej taktyka i metodyka oględzin oraz sporządzania dokumentacji z miejsc upadków z wysokości w terenie eksponowanym i jaskiniach jest rozwiązaniem autorskim bazującym na doświadczeniu zawodowym ratowników górskich, techników kryminalistycznych oraz członków zespołów oględzinowych.

Wypadki w terenie eksponowanym i jaskiniach często związane są z upadkiem z wysokości, dlatego oględziny powinny obejmować zarówno miejsce, w którym odnaleziono ratowanego lub ujawniono zwłoki ludzkie, 
miejsce, z którego przypuszczalnie spadł, jak i drogę przemieszczania się ciała w trakcie upadku ${ }^{1}$ (tor lotu).

Ustalenie przyczyn tego typu wypadków jest niezwykle trudne, dlatego oględziny i dokumentacja powinny być rzetelne i metodyczne. $\mathrm{Z}$ obserwacji autorów wynika, iż poruszanie się w terenie eksponowanym i jaskiniach wymaga nie tylko specjalistycznego przeszkolenia, ale również odpowiednich predyspozycji psychofizycznych. Wykonywanie czynności oględzinowych i dokumentacyjnych przez funkcjonariuszy nieposiadających wieloletniego doświadczenia w poruszaniu się $\mathrm{w}$ tego typu terenie niesie za sobą niebezpieczeństwo pominięcia szczegółów istotnych dla później prowadzonego postępowania. W opinii autorów głównym powodem takiego stanu rzeczy jest brak specjalistycznego przeszkolenia funkcjonariuszy oraz brak procedur jasno określających sposób i zakres współpracy z innymi podmiotami prowadzącymi działania ratownicze $\mathrm{w}$ terenie eksponowanym i jaskiniach, takimi jak GOPR czy TOPR.

Należy się jednak zastanowić, czy takie przeszkolenie jest konieczne dla członków zespołów oględzinowych i czy istnieją inne możliwości właściwego sporządzenia dokumentacji i zabezpieczenia dowodów zgodnie z wymogami prawnymi.

Zdaniem autorów jednym z rozwiązań jest włączenie do składu zespołów oględzinowych specjalistów będących ratownikami górskimi, co pozostaje w zgodzie z Zarządzeniem Komendanta Głównego Policji z dnia 23 grudnia 2004 roku. Ratownika górskiego można również powołać jako biegłego ad hoc, czyli jako osobę posiadającą wiedzę specjalną. Pamiętajmy, że na miejsce wypadku w terenie eksponowanym i jaskiniach w pierwszej kolejności dysponowane jest Górskie Ochotnicze Pogotowie Ratunkowe $^{2}$ (zgodnie z ustawą z dnia 18 sierpnia 2011 roku o bezpieczeństwie i ratownictwie w górach i na zorganizowanych stokach narciarskich) posiadające odpowiednie siły i środki. Wydaje się więc zasadne, aby odpowiednio przeszkolony ratownik górski będący pełnoprawnym członkiem

1 M. Całkiewicz, Oględziny zwłok i miejsca ich znalezienia, Warszawa 2010, s. 100.

2 Ustawa z dnia 18 sierpnia 2011 roku o bezpieczeństwie i ratownictwie w górach i na zorganizowanych stokach narciarskich, Dz.U. Nr 208, poz. 1241. 
zespołu oględzinowego, równolegle do prowadzonych działań ratowniczych, miał możliwość sporządzenia dokumentacji spełniającej wymogi formalnoprawne, zwłaszcza w miejscu, które wymaga użycia technik alpinistycznych. Celowe jest więc przeszkolenie określonej liczby ratowników górskich w zakresie prowadzenia dokumentacji oględzinowych i zabezpieczenia śladów lub dowodów w miejscu zdarzenia o charakterze upadku $\mathrm{z}$ wysokości w terenie eksponowanym i jaskiniach. Zdaniem autorów wydelegowani ratownicy powinni przejść szkolenie w tym zakresie, przeprowadzone przez laboratorium kryminalistyki właściwej miejscowo komendy wojewódzkiej policji, zakończone wydaniem stosownego zaświadczenia.

\section{Teren działania GJ GOPR}

Terenem działania Jurajskiej Grupy Regionalnej GOPR (GJ GOPR) jest obszar Wyżyny Krakowsko-Wieluńskiej położonej na terenie województwa łódzkiego, śląskiego i małopolskiego w następujących powiatach:

— wieluńskim,

- pajęczańskim,

— kłobuckim,

- częstochowskim,

- myszkowskim,

— zawierciańskim,

- Dąbrowa Górnicza,

- będzińskim,

- olkuskim,

- chrzanowskim,

— krakowskim.

Cechami charakterystycznymi krajobrazu Wyżyny Krakowsko-Wieluńskiej, potocznie nazywanej Jurą, są liczne doliny, wąwozy, jary, ostańce wapienne oraz podziemny świat jaskiń. Na terenie Jury występuje około 1500 jaskiń. Dogodne położenie i dobra sieć dróg wpływają na stały rozwój różnego rodzaju form turystyki i sportów ekstremalnych, takich jak wspinaczka skalna czy taternictwo jaskiniowe, których konsekwencją mogą być wypadki śmiertelne. 


\section{Definicje}

Działania ratownicze — każda czynność podjęta w celu ochrony życia, zdrowia, mienia lub środowiska, a także likwidacji przyczyn powstania pożaru, wystąpienia klęski żywiołowej lub innego zdarzenia wynikającego z rozwoju cywilizacyjnego i naturalnych praw przyrody, niebędącego pożarem ani klęską żywiołową, stanowiącego zagrożenie dla życia, zdrowia, mienia lub środowiska, któremu zapobieżenie lub usunięcie jego skutków nie wymaga zastosowania nadzwyczajnych środków ${ }^{3}$.

Góry — obszar Beskidu Niskiego, Beskidu Wyspowego, Beskidu Średniego, Beskidu Sądeckiego, Beskidu Żywieckiego, Beskidu Małego, Beskidu Śląskiego, Bieszczadów, Gorców, Pienin, Sudetów Wschodnich, Sudetów Środkowych, Sudetów Zachodnich, Tatr, Pogórza Spisko-Gubałowskiego oraz Wyżyny Krakowsko-Wieluńskiej, z wyłączeniem obszarów jednostek osadniczych i dróg publicznych ${ }^{4}$.

Jaskinia - naturalna pusta przestrzeń (pustka) w skale (lub lodzie lodowcowym) o rozmiarach umożliwiających eksplorację przez człowieka ${ }^{5}$.

Oględziny — „czynność procesowa polegająca na szczegółowej obserwacji (wykrywanie i zabezpieczanie śladów kryminalistycznych) miejsca, osoby, rzeczy lub zwłok przeprowadzanej przez człowieka za pomocą zmysłów i z wykorzystaniem środków technicznych, w celu wyjaśnienia charakteru i okoliczności powstałego zdarzenia oraz ustalenia jego sprawcy"6.

Ratownik górski — osoba spełniająca wymagania określone w ustawie z dnia 8 września 2006 roku o Państwowym Ratownictwie Medycznym (Dz.U. Nr 191, poz. 1410 z późn. zm.) dla lekarza systemu, pielęgniarki systemu, ratownika medycznego lub ratownika oraz posiadająca

3 Ustawa z dnia 24 sierpnia 1991 roku o ochronie przeciwpożarowej, tekst jednolity Dz.U. 2009 Nr 178, poz. 1380 z poźn. zm.

4 Ustawa z dnia 18 sierpnia 2011 roku o bezpieczeństwie i ratownictwie w górach i na zorganizowanych stokach narciarskich...

5 J. Urban, Terminy ,,jaskinia”, , pieczara” oraz ,,grota” jako dziedzictwo kulturowe, Prądnik 2012, s. 123.

${ }^{6}$ L. Koźmiński, W. Miś, L. Szplit, Wybrane czynności techniczno-kryminalistyczne podczas oględzin miejsc zdarzeń bez udziału technika kryminalistyki, Piła 2010, s. 6. 
uprawnienia ratownicze lub instruktorskie w zakresie ratownictwa górskiego i specjalistyczną wiedzę z zakresu technik ratownictwa górskiego i topografii obszaru, na którym działa dany podmiot uprawniony do wykonywania ratownictwa górskiego, zatrudniona lub pełniąca służbę w tym podmiocie bądź będąca członkiem tego podmiotu.

Ratownictwo górskie - organizowanie i udzielanie pomocy osobom, które uległy wypadkowi lub są narażone na niebezpieczeństwo utraty życia lub zdrowia w górach, oraz transportowanie zwłok z gór ${ }^{7}$.

Działania ratownicze polegają na: 1) przyjęciu zgłoszenia o wypadku lub innym zdarzeniu; 2) dotarciu na miejsce wypadku z wyposażeniem ratowniczym; 3) udzieleniu kwalifikowanej pierwszej pomocy; 4) zabezpieczeniu i ewakuacji osób przebywających w górach z terenów stanowiących zagrożenie dla życia i zdrowia; 5) transporcie osób, które uległy wypadkowi lub są narażone na niebezpieczeństwo utraty życia lub zdrowia, do miejsca, gdzie jest możliwe podjęcie medycznych czynności ratunkowych przez jednostki ratownicze, o których mowa w art. 32 ust. 1 ustawy z dnia 8 września 2006 roku o Państwowym Ratownictwie Medycznym, po uprzednim uzgodnieniu miejsca przekazania osoby, której udzielono pomocy w ramach działań ratowniczych, z dyspozytorem jednostki systemu Państwowe Ratownictwo Medyczne (PRM); 6) poszukiwaniu osób zaginionych w górach; 7) transporcie zwłok z gór ${ }^{8}$.

Teren eksponowany — teren ograniczony z jednej ze stron przepaścią, stromym zboczem, żlebem, jak również miejsce, którego przejście wymaga umiejętności wspinaczkowych z użyciem sprzętu alpinistycznego, np. ostańce wapienne ${ }^{9}$.

\section{Fazy postępowania na miejscu zdarzenia $\mathrm{w}$ terenie eksponowanym $\mathrm{i}$ jaskiniach}

Na miejscu zdarzenia w terenie eksponowanym i jaskiniach nierzadko muszą współpracować różne służby, takie jak GJ GOPR, oddziały

7 Ustawa z dnia 18 sierpnia 2011 roku o bezpieczeństwie i ratownictwie w górach i na zorganizowanych stokach narciarskich...

8 Ibidem.

9 Opracowanie własne. 
straży pożarnej, prokuratura lub policja, dlatego zdaniem autorów niezwykle ważne jest, aby działania przebiegały według określonego porządku i obejmowały następujące fazy ${ }^{10}$ :

1) Czynności ratownicze — działania prowadzone od momentu przybycia zespołu GJ GOPR na miejsce zdarzenia do czasu zakończenia czynności ratowniczych z zachowaniem głównego priorytetu, jakim jest ratowanie życia i zdrowia ludzkiego.

2) Zabezpieczenie miejsca zdarzenia — działania prowadzone przez policję przy współdziałaniu GJ GOPR, straży pożarnej i leśnej, mające na celu uniemożliwienie osobom nieuprawnionym dostępu do miejsca zdarzenia oraz, w razie potrzeby, zabezpieczenie drogi ewakuacji osób ratowanych do miejsca przekazania jednostkom systemu PRM, jak również zapobieżenie zniszczeniu, uszkodzeniu lub utracie przedmiotów mogących stanowić dowody w później prowadzonym postępowaniu.

3) Procesowe zabezpieczenie miejsca zdarzenia - działania prowadzone równolegle lub po zakończeniu działań ratowniczych, oględziny miejsca zdarzenia, rzeczy, osób lub zwłok ludzkich.

4) Pozostałe czynności dochodzeniowo-śledcze — działania prowadzone równolegle lub po zakończeniu działań ratowniczych mające na celu ustalenie okoliczności zdarzenia.

5) Końcowe sprawdzenie miejsca zdarzenia — działania wykonywane po zakończeniu wszystkich czynności oględzinowych przed opuszczeniem miejsca przez zespół oględzinowy, mające na celu sprawdzenie, czy wszystkie dowody i ślady zostały zabezpieczone oraz czy na miejscu nie pozostawiono przedmiotów lub urządzeń będących wyposażeniem podmiotów uczestniczących w działaniach.

Główne priorytety oględzin, dokumentacji miejsca zdarzenia w terenie eksponowanym $\mathrm{i}$ jaskiniach

Należy zwrócić uwagę, iż teren eksponowany i jaskinie to miejsca potencjalnie niebezpieczne, dlatego głównymi priorytetami prowadzonych oględzin i dokumentacji powinny być:

10 Opracowanie własne. 
- zapewnienie bezpieczeństwa osobom biorącym udział w działaniach ratowniczych i czynnościach oględzinowych,

— zapewnienie bezpieczeństwa miejsca zdarzenia,

- dokumentacja miejsca zdarzenia,

— zabezpieczenie śladów i dowodów z miejsca zdarzenia w ramach prowadzonych czynności oględzinowych oraz na potrzeby odtworzenia przebiegu zdarzeń.

\section{Sposób dysponowania sił i środków GJ GOPR}

W sytuacji, w której zgłoszenie o wypadku wpływa najpierw do dyspozytora GJ GOPR, działania są realizowane według procedury prowadzenia działań ratowniczych. W jej ramach oraz na mocy zawartych porozumień dyspozytor GJ GOPR powiadamia następujące podmioty:

- policja,

- państwowa straż pożarna,

— jednostki systemu PRM.

W przypadku, gdy zgłoszenie wpłynie w pierwszej kolejności do policji lub państwowej straży pożarnej, to zgodnie z zawartymi porozumieniami z policją ${ }^{11}$ oraz państwową strażą pożarną ${ }^{12}$ GJ GOPR powiadamiane jest niezwłocznie.

\section{Taktyka i metodyka oględzin miejsca zdarzenia o charakterze upadku z wysokości}

Ponieważ teren eksponowany i jaskinie stanowią bardzo specyficzne miejsce do prowadzenia oględzin, autorzy proponują, aby proces ten podzielić trzy fazy: statyczną, dynamiczną i końcową.

Faza statyczna obejmuje ocenę wielkości zdarzenia, opisanie miejsca zdarzenia oraz ewentualnych zwłok bez przemieszczania czego-

11 Porozumienie w sprawie współdziałania Komendy Wojewódzkiej Policji w Katowicach i Jurajskiej Grupy Regionalnej GOPR na terenie województwa śląskiego z dnia 6 listopada 2018 roku.

12 Porozumienie w sprawie zasad współdziałania podmiotów Krajowego Systemu Ratowniczo-Gaśniczego z Grupą Regionalną GOPR - Grupa Jurajska na terenie województwa śląskiego (analogicznie małopolskiego) z dnia 21 marca 2018 roku. 
kolwiek. Informacje zebrane w tej fazie oględzin powinny pozwolić na wzajemne powiązanie przedmiotów i ewentualnych zwłok z otoczeniem i określenie kontekstu zdarzenia ${ }^{13}$. Na tym etapie ratownik wykonuje zdjęcia orientacyjne, sytuacyjne, fragmentaryczne.

W fazie dynamicznej należy zabezpieczyć wszystkie ślady i dowody oraz wykonać zdjęcia śladów i przedmiotów oraz ewentualnych zwłok. Dokonując wyboru metody poruszania się na miejscu zdarzenia, należy uwzględnić zasady bezpieczeństwa i warunki terenowe. Przemieszczanie się w trakcie prowadzonych czynności oględzinowych może przebiegać według metody odśrodkowej (tj. od punktu centralnego spiralnie lub promieniście na zewnątrz) lub metody dośrodkowej (tj. od krawędzi wyznaczonego miejsca do jego środka, spiralnie lub promieniście).

W czasie prowadzenia oględzin w sytuacji opisywanej w niniejszym tekście szczególnego znaczenia nabiera treść art. 209 § 3 Kodeksu postępowania karnego ${ }^{14}$. Chodzi o wytyczną ze strony ustawodawcy, aby oględziny przeprowadzać w miejscu ujawnienia zwłok i nie dokonywać nieuzasadnionego przemieszczania ciała lub szczątków ludzkich. Miejsce ujawnienia zwłok w górach, terenie eksponowanym i jaskiniach na pewno należy do technicznie i kryminalistycznie bardziej wymagających czynności.

Przystępując do oględzin miejsca upadku z wysokości, należy pamiętać, aby przeprowadzane czynności obejmowały miejsce, z którego poszkodowany spadł, drogę, którą przemieszczało się ciało, aż do miejsca ujaw-

13 M. Całkiewicz, op. cit., s. 40.

14 „Art. 209 § 1. Jeżeli zachodzi podejrzenie przestępnego spowodowania śmierci, przeprowadza się oględziny i otwarcie zwłok.

§ 2. Oględzin zwłok dokonuje prokurator, a w postępowaniu sądowym sąd, z udziałem biegłego lekarza, w miarę możności z zakresu medycyny sądowej. W wypadkach niecierpiących zwłoki oględzin dokonuje Policja z obowiązkiem niezwłocznego powiadomienia prokuratora.

§ 3. Oględzin zwłok dokonuje się na miejscu ich znalezienia. Do czasu przybycia biegłego oraz prokuratora lub sądu przemieszczać lub poruszać zwłoki można tylko w razie konieczności.

§ 4. Otwarcia zwłok dokonuje biegły lekarz, w miarę możności z zakresu medycyny sądowej, w obecności prokuratora albo sądu. W postępowaniu przed sądem art. $396 \S 1$ i 4 stosuje się odpowiednio.

$\S 5$. Do obecności przy oględzinach i otwarciu zwłok można, w razie potrzeby, oprócz biegłego, wezwać lekarza, który ostatnio udzielił pomocy zmarłemu. Z oględzin i otwarcia zwłok biegły sporządza opinię z zachowaniem wymagań art. 200 § 2". 
nienia ciała ${ }^{15}$. Zasadne wydaje się podzielenie miejsca zdarzenia na trzy oddzielne sektory. W dalszej kolejności należy określić SPO — stały punkt odniesienia oraz SLO — stałą linię odniesienia, których pozycję i przebieg należy wyznaczyć przy użyciu odbiornika GPS. Przeprowadzając oględziny w wyżej wymienionych miejscach, należy bardzo dokładnie wykonać pomiary odległości od ściany, wzajemnego położenia linii prostej ułożenia ciała względem linii lotu ${ }^{16}$. Niezwykle istotne jest również ustalenie, czy tor lotu ciała nie został zakłócony przez wystające skały, punkty asekuracyjne lub inne przedmioty ${ }^{17}$. Należy zatem zwrócić szczególną uwagę, czy na skale nie pozostały ślady otarć, w szczególności plamy krwawe. W wypadku kiedy ciało zostało przemieszczone przed rozpoczęciem oględzin na skutek działań ratowniczych, konieczne jest uzyskanie od ratowników bliższych informacji o miejscu odnalezienia, pozycji zastanej ciała oraz zakresie poczynionych zmian miejsca zdarzenia $\mathrm{w}$ trakcie przeprowadzonych działań ratowniczych. Oględzinom powinny również zostać poddane elementy ubioru ze szczególnym uwzględnieniem sprzętu alpinistycznego. W wypadku stwierdzenia braku sprzętu alpinistycznego należy zamieścić informację o zaistniałym fakcie w sporządzanej dokumentacji. Członkowie zespołu oględzinowego muszą zdawać sobie sprawę, iż zaistniałe zdarzenie nie zawsze jest wynikiem nieszczęśliwego wypadku i może być związane z celowym działaniem osób trzecich ${ }^{18}$.

Faza końcowa obejmuje sprawdzenie, czy wszystkie zaplanowane czynności zostały zrealizowane oraz czy wszystkie ślady i dowody zostały zabezpieczone. Na tym etapie podejmuje się również decyzję o sposobie i przebiegu transportu zwłok, który powinien być realizowany przez ratowników GJ GOPR wspomaganych w razie konieczności przez funkcjonariuszy straży pożarnej i leśnej do miejsca przekazania załodze ambulansu pogrzebowego wskazanego przez funkcjonariuszy policji.

Ratownik będący członkiem zespołu oględzinowego może przystąpić do sporządzania dokumentacji miejsca zdarzenia lub innych czynności

15 M. Całkiewicz, op. cit., s. 100.

16 Ibidem.

17 Ibidem, s. 101.

18 Ibidem, s. 100. 
oględzinowych po uprzednim otrzymaniu zgody od kierownika działań ratowniczych oraz kierownika zespołu oględzinowego, który decyduje również o zakresie i sposobie przeprowadzenia czynności.

W trakcie sporządzania dokumentacji ratownik powinien szczegółowo wykonywać polecenia wyżej wymienionych podmiotów i utrzymywać z nimi stały kontakt. Dokumentacja sporządzona przez ratownika powinna obejmować: zdjęcia miejsca zdarzenia, szkic miejsca zdarzenia oraz notatkę z przebiegu wykonywanych czynności.

\section{Zdjęcia}

Utrwalając wygląd miejsca zdarzenia, ratownik powinien wykonać następujące zdjęcia:

- orientacyjne - zdjęcia wykonywane jako pierwsze powinny obejmować miejsce zdarzenia wraz z otaczającą okolicą i punktami charakterystycznymi pozwalającymi na późniejsze zorientowanie położenia zwłok lub innych przedmiotów i śladów;

— sytuacyjne — ten rodzaj zdjęć należy wykonać przed dokonaniem jakichkolwiek zmian na miejscu zdarzenia; wszelkie przedmioty powinny zostać oznaczone cyframi; na zdjęciach należy uchwycić wszystkie oznaczone przedmioty oraz ich wzajemne położenie; zdjęcia należy wykonać z kilku kierunków, w tym również z góry;

- fragmentaryczne - dokumentujące pewien wycinek zastanej rzeczywistości mający znaczenie dla dalej prowadzonego postępowania, np. miejsce mocowania liny, miejsce rozpoczęcia poręczowania, miejsce obrywu fragmentu skały, miejsce ostatniego przelotu; zaleca się, aby w trakcie wykonywania tego typu zdjęć używać taśmy mierniczej lub skalówki;

— śladów i przedmiotów - zdjęcia wykonywane w miejscu ujawnienia śladów lub przedmiotów; konieczne jest, aby na zdjęciu znajdował się znacznik z cyfrą i skalówka, które nie mogą stanowić 80\% kompozycji obrazu, oraz aby fotografowany przedmiot był odpowiednio doświetlony; fotografia powinna uwzględniać istotne szczegóły, np. miejsce pęknięcia karabinka lub innego przyrządu, miejsce przerwania liny lub jej oplotu;

— zwłok — zdjęcia tego typu mają za zadanie utrwalenie pozycji ciała w stosunku do otaczających przedmiotów i śladów, obrażeń na cie- 
le, znamion śmierci (plamy opadowe), stanu garderoby; należy je wykonywać przed jakimkolwiek przemieszczeniem zwłok, z użyciem znacznika z cyfrą oraz skalówki.

Zdaniem autorów do dokumentacji fotograficznej miejsca zdarzenia może być również wykorzystany bezzałogowy statek powietrzny (BSP). Głównymi zaletami takiego rozwiązania są:

— dokładne odwzorowanie toru lotu ciała,

- wykonanie zdjęć z wysokości pod kątem prostym do podłoża z każdej możliwej pozycji, ze szczególnym uwzględnieniem miejsc kontaktu ciała z występami skalnymi,

- możliwość dokumentacji w trakcie prowadzonych działań ratowniczych.

\section{Szkic}

Sposób przygotowania szkicu z miejsca zdarzenia o charakterze upadku z wysokości będzie się różnił w zależności od tego, czy będzie dotyczył działań powierzchniowych czy podpowierzchniowych - jaskiń. Należy zaznaczyć, iż z uwagi na trudne warunki terenowe wykonany szkic będzie miał charakter ogólnego szkicu terenowego.

W przypadku czynności prowadzonych na powierzchni szkic może być sporządzony w oparciu o skałoplan — graficzne odwzorowanie ukształtowania ściany skalnej.

Na szkicu należy nanieść informacje dotyczące:

— umiejscowienia SPO i SLO,

— skali szkicu,

— kierunków geograficznych,

- miejsca, z którego nastąpił upadek,

- toru lotu,

— miejsc, które mogły spowodować odchylenie toru lotu,

- miejsca, w którym ciało lub zwłoki ludzkie zostały ujawnione,

— odległości wyżej wymienionego miejsca od podstawy ściany,

— wzajemnego położenia osi długiej ciała lub zwłok w stosunku do pionowej składowej toru lotu,

— miejsca ujawnienia śladów lub dowodów. 
W przypadku czynności prowadzonych pod powierzchnią (w jaskiniach) szkic może być sporządzony w oparciu o kartograficzny plan jaskini lub odwzorowanie trójwymiarowe jaskini wykonane za pomocą skanera 3D.

Na szkicu powinny być naniesione informacje dotyczące:

— umiejscowienia SPO i SLO,

— skali szkicu,

— kierunków geograficznych,

- miejsca, z którego nastąpił upadek,

- toru lotu,

— miejsc, które mogły spowodować odchylenie toru lotu,

- miejsca, w którym ciało lub zwłoki ludzkie zostały ujawnione, ściany,

— odległości wyżej wymienionego miejsca od podstawy najbliższej

— wzajemnego położenia osi długiej ciała lub zwłok w stosunku do pionowej składowej toru lotu,

— miejsca ujawnienia śladów lub dowodów.

\section{Notatka}

Sporządzając notatkę z przebiegu wykonywanych czynności, ratownik powinien kierować się następującymi zasadami:

- bezpośredniości - notatka powinna być pisana na miejscu zdarzenia;

— dokładności — w notatce należy umieścić informację o wszystkich przeprowadzonych czynnościach; wymiary należy podawać bez zaokrąglenia, z zachowaniem wcześniej ustalonego nazewnictwa (SPO, SLO);

— obiektywizmu — w notatce nie wpisuje się własnych wniosków, ocen ani interpretacji;

- komunikatywności - notatka powinna być napisana w taki sposób, aby później czytająca go osoba z łatwością mogła odtworzyć wygląd miejsca i przebieg czynności; sporządzając notatkę, należy zachować jednolitość nazw i nazewnictwa, poprawność gramatyczną, zwięzłość opisu, jednolite jednostki miar ${ }^{19}$.

19 Vademecum technika kryminalistyki, red. J. Mazepa, Warszawa 2009, s. 46, 47. 


\section{Zakończenie}

W odczuciu autorów problematyka związana z prowadzeniem oględzin jako czynności procesowej w terenie eksponowanym i jaskiniach jest niesłusznie bagatelizowana przez policję i prokuraturę. Niejednokrotnie wyżej wymienione zdarzenia w pierwszym etapie postępowania zostają zakwalifikowane jako nieszczęśliwy wypadek lub samobójstwo, dopiero dalej prowadzone czynności wykazują umyślne działanie osób trzecich. Autorzy zetknęli się również z przypadkami rażącego zaniedbania dotyczącego przeprowadzonych oględzin miejsc upadków z wysokości, zwłaszcza w zakresie dokumentacji fotograficznej oraz szkiców terenowych. W sporządzonej dokumentacji brakowało tak istotnych informacji, jak kierunek ułożenia ciała względem toru lotu, odległość od podstawy obiektu, oględziny miejsca, z którego ciało spadło, zdjęcia ogólne uwzględniające wzajemne położenie dowodów względem obiektu, z którego ciało spadło. Należy podkreślić, iż takie zaniedbania są niestety nie do naprawienia. W ocenie autorów taki stan rzeczy jest spowodowany brakiem odpowiednich umiejętności, doświadczenia oraz sprzętu do prowadzenia działań w terenie eksponowanym i jaskiniach, ale również brakiem wiedzy dotyczącej możliwości prawnych współpracy policji i prokuratury z innymi instytucjami. Jak wykazano w niniejszym opracowaniu, organy ścigania posiadają narzędzia prawne pozwalające na włączenie ratowników GJ GOPR do zespołów oględzinowych i właściwe wykorzystanie ich sił i środków. Należy jednak pamiętać, że włączenie ratowników GJ GOPR do składu zespołów oględzinowych może nastąpić jedynie po specjalistycznym przeszkoleniu w laboratorium kryminalistycznym, jak również po opracowaniu odpowiednich procedur współpracy i interdyscyplinarnych rozwiązań, których propozycje zostały przedstawione $\mathrm{w}$ opracowaniu.

\section{Bibliografia}

Całkiewicz M., Oględziny zwłok i miejsca ich znalezienia, Warszawa 2010.

Koźmiński L., Miś W., Szplit L., Wybrane czynności techniczno-kryminalistyczne podczas oględzin miejsc zdarzeń bez udziału technika kryminalistyki, Piła 2010.

Urban J., Terminy ,,jaskinia”, ,pieczara” oraz ,grota” jako dziedzictwo kulturowe, Prądnik 2012.

Vademecum technika kryminalistyki, red. J. Mazepa, Warszawa 2009. 


\section{Akty prawne}

Porozumienie w sprawie współdziałania Komendy Wojewódzkiej Policji w Katowicach i Jurajskiej Grupy Regionalnej GOPR na terenie województwa śląskiego z dnia 6 listopada 2018 roku.

Porozumienie w sprawie zasad współdziałania podmiotów Krajowego Systemu Ratowniczo-Gaśniczego z Grupą Regionalną GOPR — Grupa Jurajska na terenie województwa śląskiego (analogicznie małopolskiego) z dnia 21 marca 2018 roku.

Ustawa $\mathrm{z}$ dnia z dnia 24 sierpnia 1991 roku o ochronie przeciwpożarowej, tekst jednolity Dz.U. 2009 Nr 178, poz. 1380 z poźn. zm.

Ustawa z dnia 18 sierpnia 2011 roku o bezpieczeństwie i ratownictwie w górach i na zorganizowanych stokach narciarskich, Dz.U. Nr 208, poz. 1241.

\section{Visual inspection and documentation of fall events in exposed areas and caves with the participation of mountain rescuers from the Jura Upland}

\section{Summary}

The article is devoted to issues related to the use of forces and resources of mountain rescue teams during visual inspection of incident areas in exposed areas and caves. The article presents general assumptions about the organization and coordination of this type of inspection from the moment of receiving information about the event and the start of rescue operations by GJ GOPR, until the completion of collecting and securing all information and evidence as part of the inspection of the incident scene. The article contains issues related to the exchange of information between the involved entities, preparation of documentation meeting formal and legal requirements by trained GJ GOPR rescuers, securing items that may constitute evidence in subsequent proceedings, and the handling of human corpses and remains.

Keywords: visual inspection, exposed area, caves, mountain rescuers, drones, 3D scanner. 